\title{
Małgorzata SIERPIŃSKA
}

\subsection{STEREOTYPES ASSOCIATED WITH THE MAN'S AND WOMAN'S ROLE AS PROFESSIONALS}

\begin{abstract}
Summary
In our society, certain stereotypes are deeply rooted and present us with limited vision, based on a simplified knowledge and unfair opinions. They determine human attitudes towards social groups, religious groups or other nationalities, expressing durable, often unfair judgments. One of the many social situations, where the influence of stereotypes is evident, is associated with the perception of role fulfilling by women and men. Certain social and professional roles are attributed to them, and going beyond their framework is often subjected to critical evaluation. Eliminating traditional gender stereotypes is still a big challenge and the crucial matter for equalizing opportunities for women and men in family life, the process of education and in the labour market. Despite of the law regulates gender equality on most planes, and declared support for equalizing opportunities is very high in the society, the stereotypes about women and men still alive. Such stereotypes become an obstacle to the mutual understanding in the career field. Unfortunately, the stereotypes about gender roles are deeply ingrained. They usually come from the assumptions about the roles, skills and features attributed to women and men according to the cultural norms and tradition. Gender stereotypes usually derive from the diversity of roles that men and women have to fulfil in the society. The aim of this article is to make aware that equal treatment of women and men in the labour market at the stage of recruitment gives an entrepreneur the advantage by increasing a spectrum of potential skilled workers. Additionally, it can be a source of clear business profits.
\end{abstract}

Keywords: stereotype, prejudice, discrimination, mechanisms of stereotyping, gender roles

\section{Structure, concept, and functions of gender stereotypes}

We meet with many kinds of stereotypes concerning almost every area of human life. Stereotypes define the world, presenting its limited vision, based on ignorance and unfair opinions. These difficult to eradicate beliefs determine people's attitudes, e.g. to certain social or religious groups, or other nationalities, formulating permanent, often unfair judgments. (Mandal, 2004)

In the social sciences, the concept of sex in the biological dimension is more and more often distinguished from the concept of gender in the sociocultural dimension. In English, sex/gender is defined in the first sense as the term "sex", and in the sense of socio-cultural category - the term "gender". The concept of gender is thus linked to the social, cultural and psychological dimension of meaning imposing on people 
depending on their biological sex, and is applied to the social nature of the differences between the genders (Pankowska, 2005).

The term "gender" originally meant in English grammatical gender, but in the psychological literature it acquired a much wider significance, particularly in discussions contrasting psychological sex with biological sex (Czapiński, 1996).

Gender, being a universal and easily identifiable feature, is particularly vulnerable to stereotyping. In the literature of subject, the term "gender stereotypes" is used interchangeably with the following concepts: "stereotypes based on gender", "stereotypes of cultural gender", "stereotypes of socio-cultural gender", "stereotypes of psychological gender", as well as with more rarely used terms such as "masculinity and femininity stereotypes".

Gender stereotypes are generalized beliefs about psychological traits of men and women, as well as measures appropriate for one or the other sex. Gender stereotypes are easy to notice when in a statement there appear formulations such as: "women should ...", "men are more...", "women like it when ...", , "for a man he is ...", etc.

It is worth noting the burden of gender stereotypes is noticeable on many planes: from the dominant in Poland family model based on the double burdening of women with family responsibilities and occupational duties, through the process of education, job recruitment or labour market situation. Gender stereotypes create simplified descriptions of a masculine man and a feminine woman.

Stereotypes of femininity and masculinity and consist of four elements. These components are:

- $\quad$ stereotypes about physical appearance (including physical appearance of women and men),

- stereotypes about social roles,

- stereotypes about personality traits,

- stereotypes about professions

The component of physical appearance is highly correlated and affects other elements of the stereotypes of masculinity and femininity, being the most identifiable and accessible in interpersonal realities. One perceives the rest of the components of gender stereotypes from the angle of physical characteristics of an individual.

The stereotypes of personality traits of gender are a set of psychological traits and behavioural characteristics, which in a given culture are attributed to each sex (Królikowska, 2011). Stereotype of masculinity relates to agency and the stereotype of femininity - to social relationships. He stresses that within the basic personality only two moderately or highly differentiate the gender: assertiveness with a predominance of men, and sensitivity to others with a predominance of women. Furthermore, women are characterized by a slight but not accidental predominance of trust, sociability and anxiety, although the latter outcome does not apply to social anxiety, where no differences are found. Similarly, no differences are found in many other personality traits. (Wojciszke, 2002a)

At this point, it is worth mentioning, that stereotypes regulating social behaviour of men and women determine which images they should hand over to the environment. In most societies it is required from men to behave in social situations in a dominant, selfconfident and tough way, while women are expected to present submissive and empathic 
behaviour. Behaviour contrary to gender stereotypes meet with social disapproval. However, behaviour consistent with representative norms applicable to both sexes are rewarded socially, even if it is obvious they are only "putting on masks".

Women who work in public sector, business women and those pursuing career in politics are well aware of this fact. These women, creating their public image, apart from professional or political competence, also emphasize their ,feminine characteristics."

However, gender role stereotypes refer to the set of beliefs on the types of activity perceived as suitable for men (providing for a family) and for women (care and childrearing), appropriate. These roles involve stereotypes about professions.

It is stereotypically considered, therefore, that men, perform well in professions requiring physical strength, determination in action, fast decision making, and in professions requiring leadership skills and managing. Women on the other hands perform well in professions that are an extension of their family roles, that is, professions related to helpfulness, protectiveness, showing empathy and those which require communication skills. (Królikowska, 2011)

Stereotypes about different areas of professional roles of women function when it comes to driving a car. A common stereotype is the functioning stereotype of women as worse drivers than men. The negative consequence of using this type of simplification is the risk of mistakes made in such an assessment

\section{Gender Stereotypes - empirical research}

Gender stereotypes are widely known. The characteristics of one or the other sex are easily defined by almost every person. The first study on gender stereotypes just focused on creating such type of lists describing such characteristics. The study on these characteristics focused on two issues: the belief that men are assertive and have control (instrumental traits) and the belief that the domain of women is taking care of the interest of other people (expressive or pro-social traits).

Study of thirty representatives of equal nationalities, have showed a relatively great similarity in attributing specific traits to both woman and men. Women were usually perceived as striving after establishing bonds (affiliation), taking care of upbringing and showing a need for respect and men as stronger and more active, showing a strong need for success, autonomy, dominance, aggression, and It was differently referred to the issue of distinguishing ,feminine" and "masculine” traits. (Deaux and Kite, 2002) Gender stereotypes are a consequence of mental traits and behavioural characteristics which, in a given culture as characteristic, are more frequently attributed to one sex in comparison with the other. Different studies prove the existence of men and women and stereotypes similar in all studied cultures concerning different traits described as "masculine" (associated with confidence, risk-taking, independence, aggression, competence and rationality) or "feminine" (mostly associated with emotions, warmth, sensitivity, protectiveness, ability to make sacrifices or submissiveness (Mandal, 2004). It is worth mentioning that the influence of the media on the process of moulding and strengthening stereotypes is undeniable. For example, it often presents a negative 
image of feminists emphasizing their confrontational and radical nature. Such statements may become the basis for making hasty judgments.

In advertisements that refer to gender differences, the experts are usually men, and women have traditional social roles of a mother and housewife.

Stereotypical image of women in advertising is presented in the form of: caring wife and mother, woman-vamp oozing sex appeal and occasionally, emancipated woman driving fast cars, holding a reporter's microphone in their hands or holding business talks. (Doliński, 1998)

Rosenkrantz and his collaborators originally claimed that there are many more male than female characteristics that must be assessed as positive ones. However, no differences were found in the average ,positiveness" of both groups of stereotypical traits estimated with the use of average results. Recent Eagly and other's works reveal that traits attributed to women are, in fact, more favourable than traits attributed to men.

Gender differences are also strengthened in magazines. The study shows that randomly selected teen magazines such as "Bravo" or "Girl" are dominated by the subject of sex, fashion, cosmetics and music. Rarely can you find articles on education or career aspirations, and the subject of economics, politics or scientific discoveries does not exist at all, as opposed to men's magazines (Pankowska, 2005).

Rosenkrantz and his collaborators originally claimed that there are many more male than female characteristics that must be assessed as positive ones. However, no differences were found in the average ,positiveness" of both groups of stereotypical traits estimated with the use of average results. Recent Eagly and other's works reveal that traits attributed to women are, in fact, more favourable than traits attributed to men.

Pratto notes, male dominance has been recognized as characteristic of the human species. The simplest explanation of different access to power, position and social roles would be differentiation between men and women in terms of political and social characteristics.

The review of empirical literature from different countries showed women's orientation oriented toward social relationships as communal characterized by emotional closeness, taking care of others and mutual connections, and he contrasts it with task orientation (agentic), characterized by efficiency and strength. In a random group of Swedish and British teenagers, young women turned out to be less racist, more prone to support social equality and less conservative in political-economic issues than young men. (Wojciszke, 2002b)

\section{The consequences of strengthening gender stereotypes in the organization.}

The result of copying stereotypes is the phenomenon of occupational segregation of women and men. The emergence of occupational segregation results in the effect of „self-fulfilling prophecy" which was described by Robert Merton. If there is a stereotype of a woman as a housewife and superstition that women are not suited to politics, they will rarely run and be elected which will result in the domination of men in parliament and will serve as an argument strengthening the anti-woman superstition 
and megalomania of men (Sztompka, 2002). In most cultures, gender stereotypes reflecting the social stratification, they treat women in a more negative or ambivalent way, and glorify masculine values, so their acceptance means for women more negative consequences. However, it happens that also men often become the victim of gender stereotypes.

In the case of men, the consequences of the high acceptance of gender stereotypes may be associated not so much with the negative self-image as overestimating one's possibilities and setting oneself a target which is inadequate to one's abilities or situation. Low self-esteem exposes an individual to experiencing failures, disappointments, and the proverbial "banging one's head against a brick wall". On the other hand, focus on work, strength, rationality and domination is not necessarily beneficial for men as it may lead to rivalry, workaholism and health problems resulting from behaviour related to risk taking, stress, frustration and conflict. Adverse phenomena are also exclusion from the network of informal contacts, stereotype of a successful man - in the case of women, with a negative emotional tinge (success at the expense of family life), and the problem of sexual harassment. (Mandal, 2004)

In the case of women, consequences of gender stereotypes rely on generating: low selfconfidence, low self-esteem and image of one's own competence, negative body image, defensiveness, excessive dependence on others and fear of success. However, in terms of perception of themselves, women often reveal "modesty" behaviour " such as submissiveness, conformism and passivity.

Gender stereotypes are associated with sexism which is already gender discrimination. The word is derived from the English word "sex" and expresses the view that men and women are not equal. The term "sexism" stands for discrimination because of sex, as well as a set of views that make up the kind of "ideology" which treat one of the sexes - women or men - as worse.

In the sphere of functioning in the labour market sexism affects women more frequently, and in the sphere of family life - men (e.g. reluctant granting a father custody of a child in case of divorce). Sexism is a peculiar ideology and a set of extremely stereotypical beliefs delivering apparent "justification" of lower status of women in society, at work, in politics and family life. Negative phenomena in the organization from the perspective of gender stereotypes are among other things: workfamily conflict associated with combining family and professional roles, discrimination in employment (in most cases, there is discrimination against women) with all consequences, e.g. barriers to promotion or differences in salary.

On the Polish market women despite legal regulations, high qualifications and a growing number of women graduates, experience discrimination because of sex. Starting with the problem of finding work by young women, because of their possibility of pregnancy and the risk to go on maternity leave, and ending at lower salary for the same job or the problems with promotion. (Karczewska, 2015)

Adverse phenomena are also exclusion from the network of informal contacts, stereotype of a successful man - in the case of women, with a negative emotional tinge (success at the expense of family life), and the problem of sexual harassment. (Mandal, 2004) 


\section{Conclusion}

The harmfulness of strengthening gender stereotypes is obvious. The result of copying stereotypes is the phenomenon of occupational segregation of women and men. It has an influence on the kind of undertaken professional job by women and men, and its assessment by the environment. As a result, gender roles lead to the fact that many people find them characteristically rigid and imposing restrictions. Certainly, an interesting idea is to look at the stereotypes of gender roles from a wider perspective, which would mean restricting their action in favour of androgenic approach. Thus, the traditional roles defining is the opposite of a comprehensive and complete development leading to many real risks to which individuals treating them as ideal standards for themselves and social relations may be exposed to. In contemporary changing world, functionality and usefulness of gender stereotypes as "images that we carry in our heads" is getting smaller. These stereotypes carry more and more subjective and interpersonal problems, and much less benefits, contained in - as in the past - in the sense of security guaranteed by following after them. The world of the 21 st century, if it is to be perceived as modern and liberal, should strive for the gradual abolition of negative divisions resulting from the gender (especially visible in the professional sphere) in favour of equality, tolerance and partnership. Realizing this fact especially by entrepreneurs can result in abolishing unnecessary barriers within the organization, which may increase the spectrum of potential skilled workers and could also be a source of clear business profits.

\section{References}

1. Czapiński J. (ed) (1996): Psychologia społeczna. Encyklopedia Blackwella. Wyd. J. Santorski Warszawa

2. Deaux, Kite M. [w] Wojciszke B. (ed) (2002): Kobiety i mężczyźni odmienne spojrzenie GWP Gdańsk

3. Dolinski D. (1998): Psychologia reklamy Agencja reklamowa „Aida” s.c. Wrocław

4. Karczewska A. (2015): Polki w rodzinie i na rynku pracy [w] Szajt M (red) Zeszyty Naukowe Politechniki Częstochowskiej nr 15., Częstochowa

5. Królikowska S. (2011): Rola stereotypów płci w kształtowaniu postaw kobiet i mężczyzn wobec zdrowia, Nowiny Lekarskie p 80,

6. Mandal E. (2004): Podmiotowe i interpersonalne konsekwencje stereotypów związanych z płcią . Wyd. Uniwersytetu Śląskiego Katoweice

7. Mandal E. (2004): Stereotypowe postrzeganie ról kobiet i mężczyzn jako wyznacznik karier zawodowych i funkcjonowania na rynku pracy [w] Płeć a możliwości ekonomiczne w Polsce: czy kobiety stracily na transformacji? Warszawa

8. Pankowska D. (2005): Wychowanie a role płciowe, GWP Gdańsk,

9. Pratto F. (2002b): Polityka płci i różnice miedzy kobietą a mężczyzną w sypialni, kuchni i gabinecie Wojciszke B. (ed) Kobiety i mężczyźni odmienne spojrzenie GWP

10. Starowicz L. (1999): Słownik Encyklopedyczny Miłość i Seks" Wydawnictwa Europa., Wrocław

11. Sztompka P. (2002): Socjologia. Analiza społeczeństwa. Wyd. Znak 2002, Kraków

12. Wojciszke B. (2002a): Człowiek wśród ludzi. Wyd. naukowe Scholar, Warszawa

13. Wojciszke B. (ed) (2002b): Kobiety i mężczyźni odmienne spojrzenie GWP Gdańsk 